FOLIA SCANDINAVICA VOL. 23 POZNAŃ 2017 DOI: $10.1515 / \mathrm{fsp}-2017-0006$

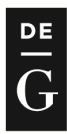

DE GRUYTER OPEN

PRESSto.

\title{
LITERATURE
}

\section{HENRIK HAJDUS (1890-1969) ROLLE I UDBREDELSEN AF DET 19. OG 20. ÅR- HUNDREDES DANSKE LITTERATUR I UNGARN}

\author{
GÁBOR ATTILA CSÚR
}

Eötvös Loránd University, Budapest

ABSTRACT. The Hungarian literary translator Henrik Hajdu (18901969) was one of the most extraordinary persons in the history of translating Scandinavian literature into Hungarian. Aside his activity as a translator from Norwegian and Swedish, Hajdu was also an important promoter of Danish authors of the 19th and 20th century. He held lectures on Nordic culture and literature, wrote reviews in prominent Hungarian journals and maintained regular contact to many of the Scandinavian publishers, writers, dramatists and poets. He translated novels by Henrik Pontoppidan, Martin Andersen Nexø and Sigrid Undset, made an edition of Ibsen's complete works and a great amount of short stories and poems. His oeuvre numbers about a hundred separate publications. This paper focuses on how he contributed to the general acceptance and reception of Danish literary works written between 1850 and 1930 among the Hungarian readers.

\section{EN PIONER I UNGARSK OVERSÆTTELSESPRAKSIS - INDLEDNING}

Henrik Hajdu var en fremragende ungarsk lyriker og oversætter fra skandinaviske sprog, der som en af de få første ikke brugte tysk eller fransk som formidlersprog. Selvom det er en selvfølge i dag, at man skal have tæt kontakt til kildesproget, forholdt det sig anderledes i lang tid i Ungarn. Det var det tyske sprogmiljø, der tjente som et fælles mødested for Nordeuropa og Ungarn. Indtil det tidspunkt, da de første primære oversættere ${ }^{1}$

${ }^{1}$ Dvs. dem, der kunne forstå og bruge de primære sprog (dvs. dansk, norsk og svensk), som f.eks. Henrik Hajdu, Margit G. Beke (1890-1989) eller Lajos Mikes (1872-1930). 
dukkede op på den litterære scene, havde man arbejdet på grundlag af de tyske oversættelser. Ungarn havde jo i forvejen gode og tætte kontakter med den tyske kultur, som i århundreder og især i perioden Østrig-Ungarn (1867-1928) gav al international viden videre til et mindre sprogssamfund.

Before the second World War the most important and most frequently used foreign language in Hungary was German, which has a centuries' old history and tradition in the country and used to be a veritable second language even of the state up to the middle of the last century. (Bart og Klaudy 1996:26)

Hajdu er noget af en pioner i eftertidens øjne. Så tidligt som i starten af det sidste århundrede kastede han sig ud i at læse norsk, dansk og svensk selvstændigt, med henblik på at kunne bruge sprogene professionelt i fremtiden. Sidstnævnte viste sig at være en svær opgave. Der var nemlig mange som havde erfaring med nordisk litteratur i forvejen, men bortset fra en lille gruppe polyglotter (f.eks. Vilmos Györy og Károly Erdélyi, der henholdsvis kunne tale svensk og dansk), forstod de ikke andet end tysk eller fransk. Hajdus indsats med hensyn til at oversætte en lang rækker titler kan virke imponerende ${ }^{2}$, men det at han lærte tre sprog på egen hånd, markerede en milepæl i ungarsk oversættelseshistorie.

Med sit arbejde mellem 1917 (hans allerførste artikel om Peer Gynt i Nyugat) og 1969 (hans død) bidrog Hajdu væsentligt til udbredelsen af den skandinaviske litterære kanon i den ungarske kulturoffentlighed. Det skete ikke udelukkende ved at oversætte primærværker, men også ved at holde foredrag, skrive tidsskrift- og avisartikler, kontakte forfatterne og at være politisk aktiv. Hans måske mest aktive år indtil anden verdenskrig faldt sammen med en livlig periode i Ungarns litteraturhistorie.

Hvis der for knap hundrede år siden udkom en ny roman, en ny novellesamling af en skandinavisk forfatter [i Ungarn], eller hvis der blev opført et skuespil på et af teatrene, kom det mest toneangivende litterære tidsskrift [Nyugat] straks med nyheder og anmeldelser og moraliserede over dem. Den skandinaviske litteratur var i lige så høj grad et forbillede som den franske eller den tyske, og værkerne blev udgivet igen og igen. (Annus 2012:157) ${ }^{3}$

Hajdus rolle kan altså ikke helt adskilles fra den historiske kontekst, han befandt sig i. Hvis Ungarns læserpublikum ikke havde været så modtageligt

${ }^{2}$ Omkring 20 romaner og et utal af digte og teaterstykker.

3 “Alig száz évvel ezelött, ha megjelent egy új regény vagy novellakötet egy skandináv szerzőtől, vagy bemutatták valamelyikük darabját valamelyik színházban, a magyar irodalmi élet meghatározó folyóirata azonnal hírt adott, recenzált, kritikát közölt és tanulságokat vont le. A skandináv irodalom ugyanúgy példaképnek számított, mint a francia vagy a német, a skandináv szerzők művei pedig újabb és újabb kiadásokat értek meg." (Min oversættelse). 
over for de nye bølger, hvis det ikke havde været den kulturelle åbnings og den politiske mangfoldigheds tid i mellemkrigstiden, ${ }^{4}$ kunne han formentlig ikke have udfoldet sine talenter.

Selvom den danske litteraturhistoriker Poul Carit Andersen (1951) også har fremhævet hans indiskutable rolle i for eksempel oversættelsen af Henrik Pontoppidans romaner til ungarsk, findes der ingen indgå ende forskning $i$ hans oversættervirksomhed eller i hans effekt på eftertiden hverken på dansk eller ungarsk. ${ }^{5} \mathrm{I}$ den foreliggende gennemgang af biografiske detaljer og litteraturhistoriske fakta sættes der fokus på udgivelsen af danske romaner og noveller fra perioden 1890-1930, digte mellem 1850-1930, i håbet om at kunne give svar på, hvorfor Hajdu kan betragtes som en af de vigtigste kulturformidlere for nordisk prosa og lyrik i landet. Forhåbentlig bliver artiklen fulgt af en anden studie i fremtiden, som vil vedrøre hans norsk-relaterede udgivelser.

\section{OM KILDERNE}

Det har været ret vanskeligt at skelne mellem historiske fakta og overdrivelser i det forhåndenværende materiale om Henrik Hajdu. Da han muligvis var en af de få favoriserede partitro oversættere, der fik mulighed for en bredere offentlig anerkendelse i Ungarns kommunistiske æra (1946-1989), kunne enkelte biografister og journalister have gode grunde til at overdrive hans betydning, og på den måde gøre hans arbejde mere legitimt end andres. Derfor er man nødt til at omgås forsigtigt med, hvad der kan læses om ham i aviserne og tidsskrifterne før 1989. Révész (1970:22) hævder for eksempel, at Hajdu havde oversat over hundrede skandinaviske romaner til ungarsk, hvilket viste sig slet ikke at være tilfældet, i hvert fald ikke med hensyn til romaner. Et andet sted kan man læse, at han holdt omtrent fem hundrede foredrag om skandinavisk litteratur, ${ }^{6}$ og det faktum kan man desværre heller ikke bevise. I løbet af forskningsprocessen blev der meget nøje undersøgt, hvilke private breve, officielle dokumenter m.fl. man havde på de ungarske biblioteker og museer, ${ }^{7}$ og hvordan materialets inhold kunne jævnføres med de tal og påstande, der stod i avisartiklerne.

${ }^{4}$ En dybere analyse af de forskellige politiske retningers stridigheder i 1920'ernes Ungarn (den periode, hvor Hajdu kom ud i den mangfoldige litterære og politiske offentlighed) giver Romsics (2005:206-222).

${ }^{5}$ Bortset fra en kort biografi skrevet af Ferenc Révész (1970).

${ }^{6}$ Interview med Henrik Hajdu, Aftenposten, 17.11.1939, fotokopi på Országos Széchenyi Könyvtár.

${ }^{7}$ Her tænkes først og fremmest på manuskriptsamlingen på Országos Széchenyi Könyvtár og Hajdus efterladte papirer på Petőfi Irodalmi Múzeum. 


\section{EN KORT BIOGRAFI OM HENRIK HAJDU ${ }^{8}$}

Henrik Hajdu (f. Henrik Klein) blev født den 20. december 1890 i Újpest (Østrig-Ungarn). Han voksede op $i$ et fattigt arbejdermiljø, men hans digtertalent viste sig at være en udvej fra åndelig og økonomisk fattigdom. Med et digt, som der ikke oplyses noget nærmere om i kilderne, vandt han Vigyázó Ferenc-prisen i 1906, og flere af samtidens centrale litterære figurer fik øjnene op for ham. ${ }^{9}$ I 1909 udgav han sin første digtsamling med titlen Versek ("Digte"). Han lærte norsk, svensk og dansk på egen hånd, og kastede sig ud i at oversætte Henrik Ibsens Brand. Arbejdet blev trukket i langdrag, det varede $i$ flere årtier og resulterede i adskillige versioner og udgaver. Mellem 1912 og 1919 arbejdede han som redaktionssekretær på det litterære, kulturelle og politiske tidsskrift Nyugat (1907/1908-1941), der også gennem navngivningen ("Vesten") ville give udtryk for, at dets forfattere vendte blikket mod de vestlige landes nyeste samfundsmæssige og kulturelle strømninger. ${ }^{10}$ Selvom Nyugat højst blev læst af et par tusinde intellektuelle, har det især i de seneste årtier ${ }^{11}$ fået større og større betydning i den ungarske litterære kanon. ${ }^{12}$ Hajdus oprindelse havde sat sit præg på hans ideologiske overbevisning, det er derfor ikke overraskende, at han senere blev medlem i det kommunistiske og det socialdemokratiske parti. Han sad i fængsel mellem 1925 og 1926 på grund af deltagelse $i$ arbejderbevægelsen. Han rejste flere gange til Norge, gav interviews til for eksempel Aftenposten og gjorde reklame for ungarsk litteratur i de nordiske medier. Ved en rejse til Danmark i 1928 var han på besøg hos bl.a. Jeppe Aakjær og Henrik Pontoppidan. I løbet af 1920'erne og 1930'erne skrev han digte og boganmeldelser med jævne mellemrum i diverse tidsskrifter og aviser. Efter Anden Verdenskrig blev han administrerende direktør for Városi Nyilvános Könyvtár ${ }^{13}$ (1945-1948), senere institutionsleder for Fővárosi Levéltár ${ }^{14}$ (1948-1953), og samtidig fortsatte han sin oversættervirksomhed som freelancer indtil sin død i 1969.

Hajdu var allerede $i$ sit liv et kendt navn i det ungarske kulturliv og en renommeret 'ambassadør' (Radó 1966:974) for dansk, svensk og norsk litteratur i Ungarn. Ifølge kilderne blev han belønnet med diverse udmærkelser inden og uden for landegrænserne. Men selvom det bliver nævnt i flere af

${ }^{8}$ Sammensat efter Erki (1969), Révész (1970) og Kenyeres (1981).

${ }^{9}$ Som for eksempel Dezső Kosztolányi og Zoltán Ambrus. Révész 1970:22, Erki 1969

${ }^{10}$ Tidsskriftet skiftede efterhånden sit politiske standpunkt i anden halvdel af 1920'erne. Før anden verdenskrig var det mere "kosmopolitisk", "dekadent" (Romsics 2005:94) og "demokratisk" (Romsics 2005: 209), men efter krigen valgte det langsomt en mere "forsigtig liberalisme" (Ibid. Mine oversættelser).

${ }^{11}$ Først og fremmest efter Sovjetunionens fald i 1989.

${ }^{12}$ Alle årgange og numre er tilgængelige på http://epa.oszk.hu/00000/00022/nyugat.htm.

${ }^{13}$ Et af de største folkebiblioteker i Budapest. I dag: Fővárosi Szabó Ervin Könyvtár.

${ }^{14}$ Budapests stadsarkiv. 
kilderne, at han blev æresmedlem af Den norske Forfatterforening og af Dansk Forfatterforening (f.eks. Erki 1969), og senere medlem i Det Norske Akademi (f.eks. Hegedüs 1957), kunne de opremsede institutioner - efter et grundigt kig i arkiverne - ikke bekræfte hans status. Enkelte danske aviser holdt øje med Hajdus aktiviteter og berettede om for eksempel Karl Kristian Nicolaisens og Henrik Pontoppidans ungarske reception (“A dán sajtó..." 1927:13). Den danske regering forærede ham en serie af kanoniske danske litterære værker bestående af 50 bind, og han fik et eksemplar af Pontoppidans allerførste bog i førsteudgave direkte fra den daværende danske kulturminister Hans Sølvhøj (Radó 1966:974). I 1969 blev Hajdu præmieret med den norske St. Olavsmedalje. ${ }^{15}$

\section{HAJDUS PONTOPPIDAN-OVERSÆTTELSER OG LYKKE-PER-DEBATTEN}

Hajdu oversatte tre store romaner af Henrik Pontoppidan, samt en, der aldrig er blevet udgivet. ${ }^{16}$ Lykke-Per blev oversat to gange, den første variant udkom så tidligt som i 1928 på forlaget Dick. En ny oversættelse fulgte denne i 1959 på Európa, som blev igen udgivet på Kriterion i 1974. ${ }^{17}$ Bøgerne bærer på samme titel: Szerencsés Péter. Den første version fik en del kritik på grund af dens ringe sproglige kvalitet (se Zolnai 1933), men vakte også stor opsigt, og satte en livlig debat mellem højre- og venstreorienterede intellektuelle i gang. Det forjcettede Land udkom under titlen Az igéret földje i 1961 på forlaget Táncsics, og De Dødes Rige i 1966 på Európa som A halottak országa. En række ungarske teoretikere og forfattere, så som Georg von Lukács ${ }^{18}$ (1913, 1975), Gábor Miszoglád (1977), László Gergye (1996, 2000), László Kardos (1966), László Bóka (1965), Tamás Ungvári (1984) eller László og Flóra Vincze (1976) betragter Pontoppidans prosa som et vendepunkt i verdenslitteraturens udvikling. Hver gang de tager udgangspunkt i Lykke-Per i anledning af en dybere analyse, sker det med henblik på at eksemplificere en litteraturhistorisk epoke, et socialt fænomen eller en pædagogisk blindgyde. Det store antal af faglige tekster omkring romanerne tyder på, at Pontoppidan vandt for alvor indpas i den ungarske litterære bevidsthed, hvilket er ret enestående sammenlignet med for eksempel Frankrig eller de engelsktalende lande. Lykke-Per udkom på fransk først i 1947, og så sent som i 2010 på engelsk.

\footnotetext{
${ }^{15} \mathrm{http} / /$ www.kongehuset.no/tildelinger.html?tid=87752\&sek=27337\&q=\&type=\&aarstall=1967.

${ }^{16}$ Det drejer sig om Mands Himmerig. Henrik Pontoppidan havde igen rigtig Tro på, at den Bog skal blive læst og forstået udenfor Danmark" (http://www.henrikpontoppidan.dk/ text/kilder/breve/hajdu_henrik/1931_06_23.html). Enten rettede sig Hajdu efter Pontoppidans mening, eller gik manuskriptet tabt under anden verdenskrig (Révész p. 23.).

${ }^{17}$ En udateret udgave på forlaget Dante stammer formodentlig også fra 1920'erne.

${ }^{18}$ Lukács og Hajdu kendte hinanden personligt, som det fremgår af Lukács 1967.
} 
Pontoppidans rige ungarske receptionshistorie skyldes uden tvivl Hajdus ihærdige indsats, der gav ham et internationalt ry:

Allerede tidligt blev Henrik Pontoppidans værker oversat. (...) Rigt repræsenteret er Ungarn, hvilket skyldes, at den ungarske forfatter Henrik Hajdu, som har overført en række nordiske romaner til ungarsk, havde fattet særlig interesse for Henrik Pontoppidans produktion. (Carit Andersen 1951:64)

Oversættelsen af Lykke-Per udløste som nævt ovenfor en længere debat mellem anmeldere i dagblade og tidsskrifter, nemlig Nyugat, Napkelet og Magyarság i 1930'erne. Kampen om romanens endelige budskab synes at have været ensbetydende med en politisk stævnemøde mellem højreorienteretkonservative og liberal-socialdemokratiske intellektuelle. Den ene lejr understregede fortællingens samfundskritiske aspekter og universelle værdier (Hajdu 1929, Nádass 1930, Tersánszky 1932), mens den anden (Dóczy 1929, Majthényi 1932, Kállay 1938) næsten udelukkende fokuserede på Dr. Nathans familie og vennekreds, og fremhævede liberalismens og jødedommens skadelige effekt på den fælleseuropæiske identitet. I Dóczys anmeldelse bliver romanens handling desuden forkortet, åbenbart for at kunne fortolke den efter egen smag. Hvorvidt den sidstnævnte gruppe har nogen videnskabelig relevans for en nutidig læser, kan selvfølgelig diskuteres. Det er imidlertid ikke til at stille spørgsmålstegn ved, at Lykke-Per-debatten er et godt eksempel på, hvor delte meningerne var i mellemkrigstidens politiske-ideologiske kamp i Ungarn.

Enkelte anerkendte skønlitterære forfattere fik også inspiration af Hajdus oversættelser. Digteren Gábor Oláh skriver i sin dagbog i 1929 om hovedpersonen i Lykke-Per følgende: "Vi svigter i livet! En enorm lærestreg!"19 (Oláh 2002) og da Antal Szerb (1980) gav sig til at skrive kapitlet om det moderne gennebrud til sin store - og ikke rent fagligt funderet - verdenslitteraturhistorie, var Hajdus 'tolkninger' sikkert ikke ukendte for ham. Sågar roman- og novelleforfatteren Zsigmond Móricz læste Pontoppidans værker, og ifølge Hajdus egne erindringer (Hajdu 1962:1859) var det netop ham, der efter at have læst bogen på tysk - overtalte oversætteren til at gå i gang med Det forjottede Land. Samtidens ungarske litteraturfolk havde altså mulighed for at holde sig ajour med de nyeste litterære tendenser i Norden, og uden Hajdu ville Pontoppidans navn stadigvæk befinde sig udenfor landets kulturelle horisont.

Lykke-Per fik jo den største opmærksomhed, men der var også nogle blandt de andre romaner og noveller, der vakte opsigt. Fortællingen To Gange mødt, på ungarsk $A$ vándor visszatér, ser dagens lys for første gang i tidsskriftet A kékmadár i 1923. Chefredaktøren Hajdu fik direkte fra indenrigsministeriet

19 ”Az életünkben mind elbukunk! Rettentő tanulság." (min oversættelse) http://mek.niif.hu/ 01300/01327/html/olah4_3.htm. 
ordre om at lukke tidsskriftet med det samme, formentlig på grund af novellens indhold opfattet som politisk agitation (Markovits 1980:503). En novellesamling Thora van Deken fra 1929 og 1930 (for indholdet se litteraturlisten nederst) blev læst og kommenteret af Lajos Kassák (1929), en af tidens mest omdiskuterede kulturradikalister, det kan derfor ikke udelukkes, at han gjorde god reklame for bogen. Først efter en lang pause fik de ungarske læsere en ny Pontoppidan-bog, Det forjcettede Land (Az igéret földje), i 1961, og endnu en ny, De Dødes Rige (A halottak országa) i 1966. Hverken af dem tiltrak synderligt meget mediedækning, og anmeldelserne er stort set overfladiske, og handler om værkernes manglende social-realistiske kvalitet (Nádass 1961, B. \& Gy. 1961, Falus 1966, “A halottak országa” 1967).

\section{OM DE ØVRIGE OVERSÆTTELSERS KULTURELLE BAGGRUND}

Nexøs romaner vandt ikke lige så stor genklang i den litterære offentlighed som Pontoppidans prosaværker. Dette skyldes formentlig, at Nexø allerede tidligt havde indskrevet sig i litteraturhistoriebøgerne som en socialistisk forfatter, derfor var det unødvendigt at diskutere om hans politiske ståsted. Hans første bog i Hajdus oversættelse var Familien Frank (A Frankcsalád), der udkom på Népszava-dagbladets forlag. Romanen Ditte Menneskebarn (Szürke fény) blev optrykt tre gange i 1947, 1948 og 1949 på forlaget Szikra. En senere version, først under samme titel, bagefter under titlen Ditte, az ember lánya af István Jánosy blev dog mere populær, og den udkom i alt otte gange. Flittige skribenter skrev jævnligt om romanens socialistiske værdier, men en lige så lang og mangfoldig kulturdebat, der havde udfoldet sig omkring Lykke-Per, gjorde diktaturen ikke mulig.

Med hensyn til H.C. Andersens Billedbog uden Billeder kan man fastslå, at H.C. Andersens navn - takket være de forrige oversættergenerationer - var langtfra ukendt i 1958, da hans lille bog udkom på ungarsk. Ligesom i mange andre lande, betragtedes han som børnebogsforfatter, og det var Hajdu også overbevist om: "det er en hjertesag for mig, at de ungarske børn făr Andersens Billedbog uden Billeder i hænderne." 20

Antologien Skandináv líra ("Skandinavisk lyrik") fra 1936 er speciel, fordi Hajdu fik den daværende norske udenrigsminister Halvdan Koht til at skrive forord til antologien. Hans ord blev citeret i flere aviser (f.eks. "Irodalmi" 1936, "Müvészet" 1936, Alaksza 1937), sandsynligvis fordi de blev opfattet som en kulturdiplomatisk gestus: "Jeg mener, at bogen er et venskabeligt håndtryk mellem vores folk"21 (Hajdu 1936:4). En anden antologi,

${ }^{20}$ Pillanatfelvétel... 1957:2. “... szívügyemnek érzem Andersen “Képeskönyv kép nélkül” címủ mủvének eljuttatását gyermekeink kezébe” (min oversættelse).

21 "Úgy érzem, ez a könyv az észeki népek kéznyujtása a magyarok felé." (min oversættelse). 
Skandináv költök, ligeledes sammensat og redigeret af Hajdu (1964), udkom 30 år senere, men med meget indholdsmæssig overlapning med 'forgængeren' fra 1936.

\section{OVERSÆTTELSERNES SPROGLIGE VRANGSIDE}

Hajdus tekster blev ret ofte kritiseret af sprogpurister og anmeldere af flere årsager. For det første fremgår det af kilderne, at han ikke beherskede de sproglige normer, som samtidens andre oversættere var i stand til at bruge korrekt. Den dominerende tradition i Ungarn har altid været, at de udenlandske romaner skal adlyde det ungarske sprogs regler og konventioner, ${ }^{22}$ og sproget betragtes som en helhed i sig selv, og ikke tolererer individuelle sproglige nyskabelser. Man går ud fra, at Hajdu ikke med vilje ignorerede det her regelsæt. Kort sagt: han skrev og talte en speciel og uacceptabel idiolekt ifølge de kritiske røster. Gyula Zolnai, en flittig purist og oversætter fra finsk, ville i en længere anmeldelse om Lykke-Per påvise Hajdus fejl ned til mindste detalje. Han nævner eksempelvis, at oversætteren jævnligt kombinerer verber og substantiver, der ikke rigtig passer sammen: "ez [a büntudat] fölszította alázatát (Pontoppidan 1928/II:206)" (Zolnai 1933:31), dvs. "[hans skyldfølelse] fremprovokerede hans ydmyghed". De høje antal af dialektale vendinger og udtryk, som forekommer i romanen, giver også anledning til misbilligelse hos Zolnai. Hajdu kritiseres ydermere for at anvende germanismer og uungarske vendinger i for eksempel Ibsens Brand (Vekerdi 1991:874). Med nutidige øjne kan man fastslå, at der var noget ved al den kritik, som Hajdu fik for Lykke-Per og de andre oversættelser. Den følgende samling af de hyppigste 'fejl' er et forsøg på at bevise, hvorfor han stadigvæk ville blive udsat for kritik fra de fleste ungarske forlagsredaktioner, der oftest har en skarp, normativ holdning til, hvordan man skal oversætte litterære tekster.

a) Hajdu vælger tit at oversætte sætningerne således, at han beholder den originale ordstilling, hvilket selvfølgelig ikke altid kan lade sig gøre. Det lyder især mærkeligt, når der er tale om sætninger, grundleddet udgøres af en adjektivkonstruktion i ubestemt form.

En lyst behandsket Haand viste sig i Vinduesaabningen. (Pontoppidan 1971/I:78)

Egy világoskesztyüs kéz kiintett az ablak nyílásából. (Pontoppidan 1959:68)

Der er flere problemer med den her sætning. For det første står der en adjektivkonstruktion i ubestemt form med artikel ("egy világoskesztyüs kéz")

22 Jf. f.eks. en længere sammenfattende studie i litterær oversættelse i Ungarn af Józan (2009), eller Bart og Klaudy 1996. 
foran i sætningen, hvilket er yderst sjældent og antages for at være en germanisme i det ungarske sprog. For det andet er det problematisk, at verbet og præfikset ikke bliver adskilt (kiintett - intett ki), da dette fører til misforståelser omkring, hvilket element der sættes fokus på. I Hajdus version er det verbet, der står i fokus (Hvad gjorde hånden? - Den viste sig.), men det er ikke tilfældet i Pontoppidans tekst. ${ }^{23}$ Da Hajdu bruger lignende sætningsstrukturer konsekvent i bogen, kan man gå ud fra, at han tænkte, at sådan en ordret oversættelse var den rigtige måde at gengive teksten på. Underlig nok kan man læse hans ord et sted: "Hvordan kunne mon den oversætter, der ikke kan fremstille en enkel hovedsætning, have forstand på æstetisk forskning?"24 (Hajdu 1931c:346).

b) Et andet problem opstår, når det kommer til ordvalg. Somme tider støder man på mærkelige, indviklede og morsomme vendinger i Hajdus sprog. I en oversættelse af Ibsens Bergmannen finder man følgende linjer:

Dypt i fjellets øde natt

vinker meg den rike skat, diamant og edelstene

mellem gullets røde grene. (Ibsen 1991:462)
Sírsötét aknák mögött

dúskálkodnak a rögök -

gyémántokkal tüzdelt vénák

kúsznak az arany erén át. (Hajdu 1936:9)

Læser man digtet højt, opstår der nogle problemer ved sidste linje. Hajdu bruger udtrykket "arany erén át" for "mellem guldets røde grene". Genitivkonstruktionen "az arany ere" (omtrent "guldets blodkar") skal antagelig forstås som en metafor, men læser man digtet højt og uden en unødvendig pause mellem "arany" og "erén", făr man det umiddelbare indtryk, at der står "aranyér" (dvs. skrevet i et ord) i sidste linje, dvs. hæmoride. Et mere alvorligt eksempel på hans uheldige ordvalg finder man de steder, hvor han ellers kunne have gjort brug af direkte ækvivalens. I novellen $A$ bölcsek köve (De Vises Sten) skriver han "undor" (Pontoppidan 1935c:320), ${ }^{25}$ der svarer til almindelig væmmelse, lede eller ubehag, i stedet for det mere konkrete begreb "menneskeforagt" (Pontoppidan 1979:69), ${ }^{26}$ som kan oversættes til "megvetés" eller “embergyülölet".

c) Men hensyn til Hajdus sprogkundskaber kan man på grundlag af brevvekslingerne med forfattere konkludere, at han talte et meget omstændeligt og gebrokkent dansk, og han forstod tydeligvis ikke det almindelige hverdags-

${ }^{23}$ Om fokus i ungarsk se f.eks. Várnai \& Mészáros 2011:30.

24 “A fordítás művészete többek közt a gondolkodás művészete - aki egyszerű bővített mondatok fogalmazásához nem ért, hogy értsen az önálló esztétikai kutatáshoz?" (min oversættelse).

25 "A mély és néma undor!"

26 "Det er den dybe, tavse Menneskeforagt!" 
sprog. Ordforråd havde han åbenbart ingen problemer med, men hans oversættelser tager oftest fejl, når det drejer sig om hyppige, men på overfladen misforståelige strukturer (f.eks. "hver for sig"). Desuden volder ham ledsætningsordstillingen ("De maa jo vide, hvad betyder mig Deres Brev"27), den konsekvente brug af præpositioner ("andre Værker fra [/af] Dem"28) flest problemer, og manglende sætningsdele gør det tit besværligt at forstå sammenhængen ("Maaske tør derefter bede Dem om at interessere Dem for Sagen"29). Hans manglende evne til at lægge mærke til sproglige nuancer afspejles også i oversættelserne: "med Omhu anbragte han en Arm omkring hver af dem" (Pontoppidan 1979:37) oversættes eksempelvis til "omstændeligt anbragte han Armene omkring en af dem" 30 (Pontoppidan 1935b:318), og "Hold nu op!" (Pontoppidan 1979:37) til "Opfør dig ordentligt!"31 (Pontoppidan 1935b:318). Der er selvfølgelig en del frihed, når man vælger mellem forskellige løsninger, men i de fleste tilfælde kan man antagelig tale om misforståelser.

Læser man ovenstående afsnit, får man fornemmelsen af, at Hajdu ikke engang var i stand til at tale noget som helst sprog fejlfrit og konsekvent. Men så enkelt er det alligevel ikke. Det fremgår af Révész' (1970) biografi, at Hajdu tog flere tilløb til Ibsens Brand, og det kan ikke helt udelukkes, at 1930'ernes kritiske kommentarer blev taget $\mathrm{i}$ betragtning, da han startede på en frisk med Lykke-Per tyve år derefter. Foruden de tilbagevendende sværlæste passager kan læseren godt mærke den udvikling, som Hajdu havde været igennem i årene imellem. Det er også vigtigt at huske, at de første svenske, danske og norske ordbøger og lærebøger for ungarere udkommer først efter Hajdus død, han havde altså lært sprogene uden noget målsprogligt hjælpemateriale.

\section{SIDSTE BEMÆRKNINGER - HAJDUS SYN PÅ NORDEN OG KONKLUSION}

Det er beklageligt, at Henrik Pontoppidans, Martin Andersen Nexøs og en række danske digters (Johannes V. Jensen, Jeppe Aakjær, Johan Skjoldborg osv.) reception i Ungarn bærer præg af Hajdus besværlige stil og personlige opfattelse af Norden. Den her opfattelse var langt fra objektiv og neutral. Alle hans favoritter bliver omtalt i superlativer ("Mands Himmerig (...) er et værk af romankunstens største repræsentant i Norden"32 Hajdu 1931d:482, "[Jeppe

${ }^{27}$ Henrik Hajdus brev til Henrik Pontoppidan, 18.12 .1927 (http://www.henrikpontoppidan.dk/ text/seclit/secbreve/hajdu_henrik/1927_12_18.html).

28 Henrik Hajdus brev til Henrik Pontippidan, 31.07 .1927 (http//www.henrikpontoppidan.dk/ text/seclit/secbreve/hajdu_henrik/1927_07_31.html).

29 Henrik Hajdus brev til Henrik Pontoppidan, 18.12 .1927 (http:/www.henrikpontoppidan.dk/ text/seclit/secbreve/hajdu_henrik/1927_12_18.html).

30 "az egyiknek körülményesen nekifeszült"

31 "Ne bomolj!"

32 “Az északi regényírás legnagyobb művészének alkotása”. (Min oversættelse). 
Aakjær er] Danmarks største lyriker"33 Hajdu 1931a:484, "Pontoppidans absolutte mesterværk" ${ }^{34}$ Hajdu 1962:1859, "[Johannes V. Jensen er] prosaens

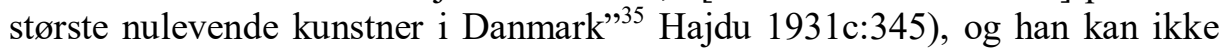
undgå at kategorisere forfatterne og nordisk skrivekunst i det hele taget ved hjælp af nogle særlige nordiske karakteristika. Det er som om der altid er noget fremmedartet, eksotisk, og mystisk i Hajdus definition af den skandinaviske antropologi, hvor Skandinavien således altid får et positivt fortegn, hvor alt er fyldt med en højtidelig stemning og heroisme ("Lykke-Pers flakken skal afkøles i den danske sandørkens ugudelige tavshed"36 (Hajdu 1929:354), "Blicher, Drachmann, Jensen, Skjoldborg, Gunnarson og Hjortø. (...) et halvt dusin vikinger, og de kan drage sejrrigt ned til Donau og Tiszas land" ${ }^{37}$ (Hajdu 1931c:345)).

Det står dog hævet over enhver tvivl, at Hajdu har bidraget markant til det 19. og 20. århundredes danske litteraturs udbredelse i Ungarn. Hvis man skal vægte fordelene og ulemperne, er det vistnok fordele, som er i overtal. Nogle bøger blev trykt i over 10000 eksemplarer, ${ }^{38}$ flere og flere ungarske teoretikere stiftede efterhånden bekendtskab med de danske repræsentanter for de vigtigste tendenser i samtidens nordiske litteratur: det moderne gennembrud, naturalisme, realisme, symbolisme samt det sjælelige gennembrud. Pontoppidans og Nexøs romaner kan også i dag købes i antikvariaterne, og Hajdus oversættelser bliver brugt som introduktionsmateriale for førsteårsstuderende på ELTE-universitetets skandinaviske institut, med stor respekt og en vis overbærenhed.

\section{LITTERATURLISTE}

\section{BIBLIOGRAFI OVER DANSK LITTERATUR PÅ UNGARSK, OVERSAT AF HENRIK HAJDU}

Andersen, H.A. (1958). Képeskönyv kép nélkül (Billedbog uden Billeder). Budapest: Magyar Helikon. Brandes, G. (1925). Anatole France I-II. Nyugat, vol. 18, nos. 5-6, 256-265.

Christian, H. (1927). Herman Bang. Nyugat, vol. 20, no. 18, 367-383 (portræt).

Hajdu, H. (red.) (1936). Skandináv líra, Ujpest, Vörösmarthy Irodalmi Társaság, 180 s. (digte af bl.a. Holger Drachmann, Jens Jacobsen, Karl Gjellerup, Herman Bang, Johan Skjoldborg, Viggo Stuckenberg, Sophus Claussen, Jeppe Aakjær, Martin Andersen Nexø).

33 "Dánia legnagyobb lírikusa." (Min oversættelse).

34 "Pontoppidan legremekebb regényét" (Min oversættelse).

35 "[Johannes V. Jensen] a dán próza legnagyobb élő művésze" (Min oversættelse).

36 "Szerencsés Péter vergődéseinek a dán homoksivatag istentelen csendjében kell lehülnie" (Min oversættelse).

37 "Blicher, Drachmann, Jensen, Skjoldborg, Gunnarsson, és Hjortö (...) a fenti féltucat viking győztesen törhet le a Duna-Tisza közé." (Min oversættelse).

${ }^{38}$ Lykke-Per-udgaven fra 1974 tæller f.eks. over 15740 trykte bøger. 
Hajdu H. (red.) (1964). Skandináv költők. Budapest: Magvető (digte af bl.a. Johannes V. Jensen, Jens P. Jacobsen, Johan Skjoldborg, Hans Hartvig Seedorff).

Nexø, M.A. (1930). A Frank-család: regény. Budapest: Népszava.

Nexø, M.A. (1932). Reggel (Morgen), Nyugat, vol. 25, nos. 9-10, 505.

Nexø, M.A. (1947). Szürke fény (Ditte Menneskebarn), bd. I-II. Budapest: Szikra [1. oplag: 1947, 2. oplag: 1948, 3. oplag: 1949].

Nicolaisen, K.K. (1927). Henrik Pontoppidan (70-ik születésnapja alkalmából) I-V. Nyugat, vol. 20, no. $15,159-169$.

Nicolaisen, K.K. (1927). Martin Andersen Nexö I-VI. Nyugat, vol. 20, no. 15, 700-712 (portræt).

Nicolaisen, K.K. (1932). Johan Skjoldborg. Nyugat, vol. 25, nos. 9-10, 600-602 (portræt).

Nicolaisen, K.K. (1932). Thöger Larsen. Nyugat, vol. 25, nos. 9-10, 599-600 (portræt).

Pontoppidan H. (1923) A vándor visszatér (To Gange mødt). A kékmadár, vol. 1, no. 10, 58-69.

Pontoppidan, H. (1928). Szerencsés Péter (Lykke-Per). Budapest: Dick.

Pontoppidan, H. (192?). Szerencsés Péter (Lykke-Per). Budapest: Dante.

Pontoppidan, H. (1929 og 1930). Thora van Deken. Budapest: Pantheon, 1929 og 1930 (indeholder novellerne Lille Rødhcette, Borgmester Hoeck og Hustru, Den kongelige Goest, To Gange mødt).

Pontoppidan, H. (192?). Thora van Deken. Budapest: Révai 192? (indeholder novellerne Lille Rødhcette, Borgmester Hoeck og Hustru, Den kongelige Goest, To Gange mødt).

Pontoppidan, H. (1932). Sasút (Ørneflugt). Nyugat, vol. 25, nos. 9-10, 506-507.

Pontoppidan, H. (1935a). Sas-út (Ørneflugt). I: G. Baktay m. fl., Nobel-dijas íók antológiája Harmincnégy arcképpel (s. 314-316). Budapest: Káldor Könyvkiadó Vállalat.

Pontoppidan, H. (1935b). Az erős szabó (Den stærke Skrædder). I: G. Baktay m. fl., Nobel-dijas irók antológiája - Harmincnégy arcképpel (s. 317-318). Budapest: Káldor Könyvkiadó Vállalat.

Pontoppidan, H. (1935c). A bölcsek köve (De Vises Sten). I: G. Baktay m. fl., Nobel-díjas írók antológiája - Harmincnégy arcképpel (s. 319-320). Budapest: Káldor Könyvkiadó Vállalat.

Pontoppidan, H. (1959). Szerencsés Péter (Lykke-Per). Budapest: Európa.

Pontoppidan, H. (1961). Az ígéret földje (Det forjættede Land). Budapest: Táncsics.

Pontoppidan H. (1965). Sasút (Ørneflugt). I: A. Martinkó, Gy. Hincz (red.), Elbeszélések a világirodalomból (s. 294-297). Budapest: Móra Ferenc Ifjúsági Könyvkiadó.

Pontoppidan, H. (1966). A halottak országa (De Dødes Rige). Budapest: Európa.

Pontoppidan, H. (1970). A halottak országa. Részlet (De Dødes Rige. Uddrag). I: I. Bernáth (red.), Észak-európai népek irodalma. Válogatás az izlandi, faeröeri, norvég, svéd és dán irodalomból (s. 427-436). Budapest: Tankönyvkiadó Vállalat.

Pontoppidan, H. (1974). Szerencsés Péter (Lykke-Per). Bukarest: Kriterion.

\section{HAJDUS ARTIKLER OM DANSK LITTERATUR I TIDSSKRIFTET NYUGAT (1908-1941)}

Hajdu, H. (1929). Szerencsés Péter. Nyugat vol. 22, no. 5, 353-354.

Hajdu, H. (1931a). Az utolsó út. Nyugat, vol. 24, no. 7, 484-485 (en kort rapportage om Jeppe Aakjærs begravelse).

Hajdu, H. (1931b). A fekete madarak. Martin Andersen Nexö könyve H. Aschehoug \& Co. Dansk Forlag Köbenhavn. Nyugat, vol. 24, no. 7, 483-484 (boganmeldelse om Martin Andersen Nexøs De sorte Fugle).

Hajdu, H. (1931c). Dán elbeszélők. Kner-kiadás. Nyugat vol. 24, no. 5, 345-346.

Hajdu, H. (1931d). Mands himmerig: Pontoppidan regénye, Nyugat vol. 24, no. 7, 482-483. 


\section{ØVRIGE HENVISNINGER}

Alaksza, A. (1937). Újpest és Rákospalota irodalma, Magyar Szemle, nos. 9-12, 163-171.

Annus, I. (2012). Irodalmi kanonizáció, avagy történetek Svédországból. I: Skandinavisztikai füzetek = Papers in Scandinavian Studies, no. 9, 157-164.

B. \& Gy., F. (1961) Az ígéret földje, Népszava, 05.08.1961, 2.

Bart, I., Klaudy, K. (1996). Translation, Translators and the Study of Translation in Hungary. I: Klaudy K., Lambert, J., Sohár A., Translation Studies in Hungary (s. 26-36). Budapest: Scholastica.

Bóka, L. (1965). Henrik Pontoppidan mühelye. In: Bóka, L. Könyvek, gondok: válogatott tanulmányok és jegyzetek (s. 328-338), Budapest: Gondolat.

Carit Andersen, P. (1951). Omkring Henrik Pontoppidan. I: S. Dahl (red.), Bogvennen. Aarbog for Bogkunst og Boghistorie, København: Fischers Forlag.

Dóczy, J. (1929). Szerencsés Péte,, Magyarság, 17.02.1929, 5-6.

Erki, E (1969). Az Élet és Irodalom látogatóban Hajdu Henriknél. Élet és Irodalom, vol. 9, no. 5,12 .

Falus, R (1966). A halottak országa, Népszabadság, 09.05.1966, 9.

Gergye, L. (1996). Pontoppidan Szerencsés Péteréről. Filológiai Közlöny, vol. 42, no. 1, 1-20.

Gergye, L. (2000). A melankólia mint létértelmezés (Pontoppidan: A halottak országa). Filológiai Közlöny, vol. 46, no. 3-4, 89-104.

Hajdu H. (1962). A skandináv irodalom szolgálatában, Nagyvilág, vol. 7, no. 12, 1853-1861.

Hegedüs, G. (1965). Észak tolmácsa. Hajdu Henrik 75 éves. Élet és irodalom, vol. 9, no. 52, 8.

Ibsen, H. (1991). Samlede verker, bd. I-II, Den norske Bokklubben.

Józan, I. (2009). Mü, forditás, elmélet. Elmélkedések. Budapest: Balassi Kiadó.

Kállay, M. (1938). Henrik Pontoppidan a zsidókérdés első nagy regényirója. Napkelet, vol. 16, no. 6, 426-429.

Kardos, L. (1966). Pontoppidan és a Szerencsés Péter. I: K. L. Közel és távol: irodalmi tanulmányok (s. 101-122). Budapest: Magvetö.

Kassák, L. (1929). Thora van Deken. Nyugat, vol. 22, no. 21, 560-561.

Kenyeres, Á. (red.) (1981). Magyar Életrajzi Lexikon, 3. bd, Budapest: Akadémiai, 281-282.

Lukács, G. v. (1913). Esztétikai kultúra: tanulmányok. Budapest: Athenaeum.

Lukács, G. v. (1967). Lukács György levele Hajdu Henrikhez, Nagyvilág, vol. 11, no. 2, 313-314.

Lukács, G. v. (1975). Az elvont idealizmus. In: L.,Gy. A heidelbergi müvészetfilozófia és esztétika. A regény elmélete: ifjúkori müvek (s. 547-559). Budapest: Magvetö.

Majthényi, Gy. (1932). Henrik Pontoppidan: Szerencsés Péter. Napkelet, vol. 8, no. 3, 281-286.

Markovits, Gy. (1980). Czakó Ambró elkobzott kiadványai a kurzus idején. Irodalomtörténet, vol. 62 , no. $12,501-512$.

Miszoglád, G. (1977). A dán regény a XIX. Században. Filológiai Közlöny, vol. 23, no. 1, 75-86.

Nádass, J. (1930). A házasság válságának írói, Korunk, vol. 5, no. 5, 395-397.

Nádass, J. (1961). Az ígéret földje. Nagyvilág, vol. 6, no. 6., 1884.

Oláh, G. (2002) Naplók. Debrecen: Debreceni Egyetem Kossuth Egyetemi Kiadója.

Pontoppidan, H. (1971). Lykke-Per, bd. I-II. København: Gyldendal.

Pontoppidan, H. (1979). Ørneflugt og andre krøniker. København: Gyldendal.

Radó, Gy (1966). A skandináv irodalmak magyar múzeumában. Jelenkor, vol. 11, no. 10, 972-974.

Révész, F. (1970). Hajdu Henrik 1890-1969. I: Fövárosi Szabó Ervin Könyvtár Évkönyve (Különlenyomat a Fövárosi Szabó Ervin Könyvtár évkönyvéböl, 1968, 1969) (s. 13-28). Budapest.

Romsics, I. (2005). Magyarország története a XX. században. Budapest: Osiris.

Szerb, A. (1980). A világirodalom története. Budapest: Magvető.

Tersánszky, J.J. (1932). Szerencsés Péter: Henrik Pontoppidan regénye. Nyugat, vol. 25, nos. 9-10, 591-592. 
Ukendt forfatter (1967). A halottak országa. Korunk, vol. 26, no. 2, 277.

Ukendt forfatter (1927). A dán sajtó és a Nyugat. Ujság, 25.09.1927, 13.

Ukendt forfatter (1936). Irodalmi napló. Pesti Napló, 15.08.1936, 42.

Ukendt forfatter (1936). Művészet, irodalom. Népszava, 18.08.1936, 4.

Ukendt forfatter (1939). Interview med Henrik Hajdu. Aftenposten, 17.11.1939.

Ukendt forfatter (1957). Pillanatfelvétel Hajdu Henrikröl. Élet és Irodalom, vol. 1, no. 23, 2.

Ungvári, T. (1984). A dán naturalizmus. I: U.,T. A modern irodalom válaszútjain (s. 53-59). Budapest: Gondolat.

Várnai, J.Sz., Mészáros, A.É. (2011). Fordítókalauz. Hogyan igazodjunk el az angol nyelvü jogi és európai uniós szövegek útvesztőjében? Budapest: Tinta.

Vekerdi, L. (1991). Csurka István: Új magyar önépítés. Életünk, vol. 29, no. 10, 866-880.

Vincze, L., Vincze, F. (1976). H. Pontoppidan: Szerencsés Péter. Elemzés. I: V.,L. og V.,F. Regényirodalom és pedagógia (s. 101-118). Budapest: Tankönyvkiadó.

Zolnai Gyula, (1933). Egy regényfordításról. Magyarosan - Nyelvmüvelö folyóirat, vol. 2, nos. 3-4, $31-37$.

\section{WEBSIDER (23.05.2017)}

http://epa.oszk.hu/00000/00022/nyugat.htm

http://www.henrikpontoppidan.dk/text/seclit/secbreve/hajdu henrik/1927_12 18.html

http://www.henrikpontoppidan.dk/text/seclit/secbreve/hajdu_henrik/1927_07_31.html

http://www.henrikpontoppidan.dk/text/kilder/breve/hajdu_henrik/1931_06_23.html

http://www.kongehuset.no/tildelinger.html?tid=87752\&sek=27337\&q=\&type=\&aarstall=1967

http://mek.niif.hu/01300/01327/html/olah4_3.htm

\section{Gábor Attila Csúr}

Eötvös Loránd University

Faculty of Humanities

Department of Scandinavian Languages and Literatures

Rákóczi út 5.

1088 Budapest

Hungary

gabor.csur@gmail.com 